\section{THE BASKING SHARK}

TO many it may be a quite new and strange fact that the Basking Shark, almost the largest fish now living, is to be commonly met with at certain seasons around the western part of the British Islands. The fine specimens recently added to the zoological collections of the British Museum and the Royal Dublin Society have excited some wonder ; but the popular mind, while it associates sharks with tropical seas and coral reefs, seems as yet hardly to have taken in the fact that if it wants to see about the biggest of all sharks in smali shoals, playfully gambuiling, it need wander no farther than to the Atlantic coast of Ireland. There, towards the end of April, and often all through May, these Basking Sharks will be met with, They have even been counted off Tory Island in shoals of from sixty to a hundred, basking in the bright morning suns of June.

It is about $I$ Io years ago since the esteemed Bishop Gunnerus (born I7i8, died 1773) published an account of this big fish in the Trondhjem Society's Journal, and a great number of authors have written on the subject since then. Under many local names-Basking Shark, Sun-fish, Pelerin-it has been well known to fishermen; it reaches a length of 40 feet, although average-sized specimens do not measure more than between 20 and 30 feet in length; of large size, and shark though it be, it would appear, like many other big animals, to be of a gentle, mild, and placid disposition, to be fond of sunning itself on bright days, and to never interfere with mankind unless when they interfere with it ; and yet with all these facts in its favour, the animal being, so to speak, common, having local names, being of a size not easily overlooked, and not being, like its cousin the Blue Shark, a man-eating devil, this Selache maximus was very little heard of and less known until the other day. Twelve months ago Dumeril, in his "Ichthyologie Générale," could with truth write about the specimen in the Museum at Paris: "Il semble être, jusqu'à présent, le seul représentant dans les Musées de l'Europe centrale de cette énorme espèce des Mers du Nord." To this moment nothing very exact is known as to its food. Pennant thought it fed on marine plants, Linnæus considered its food to be medusæ; some fishermen foolishly think it lives on herrings; and as to its times and seasons nothing is known. Why does it come from north to south, and why then go north again?

So little being known about its form and habits, it is not much to be wondered at that very little is known about its anatomy; and yet Sir Everard Home wrote an anatomical account of it, which is to be found in the Philosophical Transactions for r 809 , in which he tells us that he found in the stomach of this fish structures showing a link in the gradation of animals between the whale tribe and the cartilaginous fishes. Why, to work out this idea alone ought to send the comparative anatomists off at once to Tory Island or Bofin. ${ }^{\text {? }}$ We would, however, refer to another anatomical peculiarity, which, had it been known to Sir E. Home, would doubtless have clenched his argument, namely, the presence of rays or fringes of a whalebone-like substance along the gill-openings. It is true that Gunnerus in 1766 refers to these strange fringes; it is true that in the museum of that far north city of Trondhjem - and within view of the wondrous old cathedral where Gunnerus lies buried, and where to this day Norway's kings are crowned-there is to be seen a piece of one of them ; that other Northern Museums, those of Christiania, Kiel, and Copenhagen also possess pieces, and equally I Islands off the west coast of Ireland-well known localities for this shark. true, that during all these days Gunnerus's statements had been overlooked, and these fringes were a puzzle to everyone who examined them. Prof. Hannover, indeed, in I 867 , from their minute structure, described them, and thought they were planted on the outside of the fish's skin, like the long spines of certain rays.

Prof. Steenstrup, in whose charge the specimen we figure is, and to whose kindness we are indebted for the figure (I), having made up his mind that it did belong to the Basking Shark, proceeded to work out its history, and so came upon Gunnerus's description, which enabled him

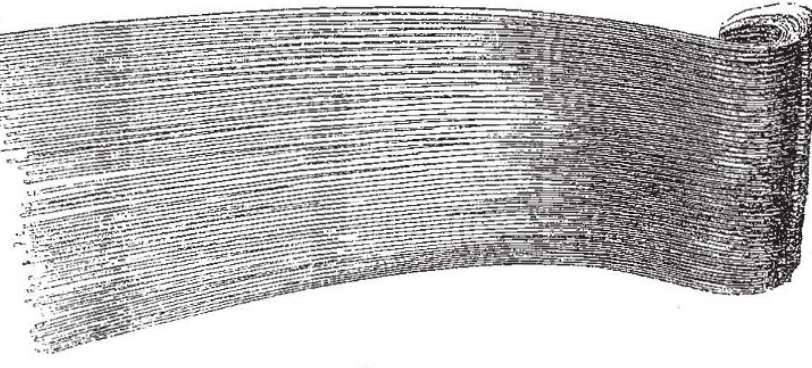

FIG. x. to suggest that this shark must have the interior of its mouth furnished with branchial fringes of a peculiar nature. He further argued that these must act as strainers; that the shark takes in whole volumes of minute food, catches it on these fringes, and then swallows it. He declares it to be a great mistake to call this fish a carnivore, that is, if he eats flesh at all, it is small flesh, not big flesh. He then objects to the writer of these lines, when describing a shark found in the Seychelles - "which is, the north whale excepted, the largest of living animals"-saying, "contrary to the habits of sharks, this one is not a carnivorous, but a herbivorous fish," as being too much on the other extreme. My excellent friend is right, and 1 have now no doubt that both these big, lubberly beasts - which in their mouth have scarcely more than the name of ter th-feed on all sorts of minute oceanic creatures, frequently taking in with them floating algæ. And he will be glid to know that, acting on the hint in his paper, when Mr. Cullen, the assistart in the Trinity College Dublin Museum, went down to Bofin in May of last year, to preserve for

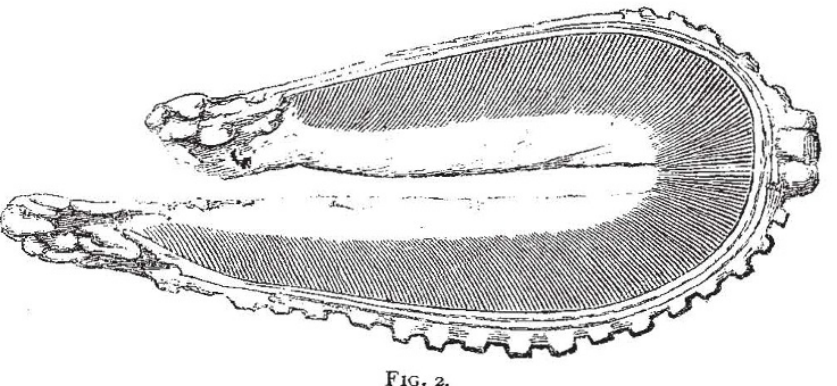

Fig. 2.

Dr. Carte the specimen now in the Dublin Museum, the first thing he did was to put his hand into the still quite fresh branchial openings, when he at once felt what Gunnerus bad felt in 1766-the whalebone-like fringes. It is to be hoped that my colleague, Prof. Macalister, will ere long give an account of this specimen; in the meanwhile a description of the annexed (Fig. 2) drawirg of these fringes-now for the first time figured in situ-will not be without some interest.

The gill-openings are five in number on each side of the neck. The first pair almost meeting on the top of the back. A thought here strikes us. As a xule these gill 
sits in the large sharks are small, here they are of immense size. Their function is to allow of sufficient water to flow in and over the gills to oxygenate the fish's blood; but in Selache they serve also as supports to the strainers ; and as so big a body must require a great lot of food, the in-takings and out-puttings must $b=$ many, and might account for the gradual increase in the size of these slits until they reacised their present immense pruportions, where th $y$ have to subierve both the functions of nutrition and circulation. The convexity of the gili-openings is towards the shark's mouth, the concaviry of these fringed rays is in the same direction. The edge represented in the drawing as jagged-an appexrance assumed in drying-is attached to the inner edge of the $\mathrm{fl}+\mathrm{ps}$ covering the gill-openings, being somewhat more firmly attached towards the central portion, which in the drawing is far too cartilaginous-looking. The gills are outside the whaltbone fringes. There seems little reason to doubt but that the free points of the fringes of the one row can be so erected from its gill ray edge as to bind forwards and join, and perhaps slighily interlace with those of the opposite row, and thus there would be a series of arches of whalebone protruding into the neck cavity of the fish. When these fringes are applied to the surface of the yill rays, the water could flow without resistance. The : ills were quite free from parasites, in this respect differing from the gills of the Rhinodon of the Seychelles. Altbough this is not the place to enter into minute details, there is little dount that Dr. Fleming is wrons in stating that the skin seems smooth when the hand is passed from the head to the tail; and yet though the scales are, as described by Dr. J. E. Gray, armed with smalt curved points bent in all directions, so that the skin teels rough each way, the hand can be rubbed sever.t times more e ssily from head to tail than frum tail to head, indicating that a larger number of the curved points are directed towards the tail.

The oil from the liver of a medium-sized Basking Shark is worth nearly $40 l$. sterling; but the difficu ties and danger of capturing these s a arks seen altogether to be greater than those attending the whale-fishery. The same was true at the Sevchelles. Men engaged at the sperm-whale fishery off St. Dinis often told me they dreaded to harpoon by mistake a Rhinodon. A whale must corne up to brearhe or else choke it-elf. But there were stories told me of how a harponned Rninodon, havin $x$ by a lighıning like dive exbausted the supply of rope, which had been accidentally fastened to the boxt, dived deeper scill, and so puled pirogue and crew to the botom-there, in spire of the harpoon in its neck and its attend $1 n t$ incumorances, it was at home for a great length of time.

\section{Ed. Perceval Wright}

\section{ON THE PHYSICAL EXPLANATION OF THE INEQUALITY OF THE TWO SEMI-DIUR- NAL OSCILLATIONS OF BAKOMETRIC PRESSURE ${ }^{1}$}

THERE are, perhaps, few phenomena in the domain of terrestrial physics which have received more attention than the diurnal variation of barumeiric prossure, and on the causts and explanation of which, nevertheless, there is more diversity of opinion even at the present day. Dove, Sabine, Herschel, Espy, Lamont, Krell, Bromn, and many others have in turn eng.tged in the discussion of this vexed problem, and at the present time Mr. A exancier Buchan is publisning an elaborate and most valuable résumé of the existins data in the Transactions of tre Royal Society ot Eainourgh as a preliminary to a renewed investinarion.

Tne ger eral fextures of the diurnai variati n of pressure are tamilar enough to every one who has ever observed the rise and fall of the barometer for a few days in Indin, and most other tropical countrits. From about 3 or 4 in the morning the pressure increases gradually towards sunrise, then more rapioly, and culminates generally between 9 and ro A.M. A fall then sets in, which becomes rapid during the hottest hours of the day, and the pressure reaches its minimum generally betwetn 4 and 5 P.M. The pressure then increases till about 10 P.M., but in general does not attain the same height as at the corresponding morning hour. Lastly, a second fall brings it to a second minimum between 3 and 4 A.M, which, except on mountain peaks and at such stations as Simla and Darjiling, is, as far as my own experience goes, never so low as the afternoon minimum. ${ }^{1}$

Thus, then, the pressure rises and falls twice in the twenty-four hours, attaining, in general, its absolute maximum about 9 or 9.30 A.M., and its absolute minimum between 4 and 5 P.M.

This may be taken as a general description of the phenomena as exhibited in the tropics; but it presents many striking variations at diterent places, and at one and the same place at different times of the year. These variations affect-the hour at which the pressure attains its maximum and minicium values, the absolute amplitude of the oscillations, and lavtly, their relative amplitude. It is this phenomenon-the varittion in the relative amplitude of the day and nisht oscillations-the probable physical explanation of which I have now to bring to notice.

It was observed by Arago, apparently some years prior to $184 \mathrm{I}$, that in Europe "Ihe proxımity of the sea has the effect of diminishing the ampitude of the interval during which the diurnal tall last ", viz., that which occurs between 9 A.M. and 3 P.M ;" and considering the whole phenomenon as made up of a single and double oscillation, it may easily. be shown that this interval is determined mainly by the relative amplitude of these two elc ments. The latest notice on the subject is given in the following extract from Mr. Buchan's Memorr, a copy of the first part of which (for which I am indebted to the author) has reached me only within the last week. In summing up the chardcieristics of the midday fall of pressure, he says:- "Wh.tever be the cause or causes on which the diurnal oscillations of the barometer depend, the ii fluence of the relative distribution of land and water in determining the absolute amount of the oscilation in particular localities, as well as over extended regions, is very great. From the facis detailed above, it will be seen that this influence gives a strong local colouring to the results, paricularly along the coasts, and that the :ame influence is extensively feit over the Channel, the Mediterranean, the Atiantic, and other sheets of water on the one hand, and on the other over the inland portions of Great Britain, Europe, and the other continents ;" and farther on he adds: "While, as has been pointed our, numerous illusirations can be adduced showing a lar $r_{p}$ er o:cillation over the some re $e_{\mp}$ ion with a high temperature and a dry atmosphere than with a low temperature and a most atmosphere, the small summer osctilation on the coasts of the Mediterranean and those of the Atlantic adjoining is in diret t opposition to the idea that any such conclusiun is general. For over those parts of the Mediterrantan and Atrantic the temperature is huttest in summer and the air is driest-so dry, indeed, that no rain, or next to none, falls; and yet there the arplitude of the oscillation now coniracts to its annual minimum. On the western coasts of the Atlantic, from the Bahamas northwards to Newfoundland, the temperature is at the annual maxiluum, but the air is not dry, being 1 berally su, plicd with misture, and the $r_{d}$ infall is generous. But with these very different meteorulogical conditions there occurs, tqually as in Southern Europe, a diminished oscillation auring the summer montas in the istands and near the $x$ Possibly some coasts may furnish an exception. 